\title{
Exogenous indole-3-acetic acid could reduce the accumulation of aluminum in root apex of wheat (Triticum aestivum L.) under Al stress
}

\author{
Q. Wang, ${ }^{1}$, F. Nian ${ }^{2}$, L. Zhao ${ }^{2}$, F. Li, ${ }^{2}$ H. Yang ${ }^{2}$, Y. Yang ${ }^{3 *}$ \\ ${ }^{1}$ Wu Han Military Economic Academy, Wu Han 430035, China, ${ }^{2}$ College of Tobacco, Yun Nan Agricultural University, Kun Ming \\ 650000, China; ${ }^{3}$ College of Life Science and Technology, Kunming University of Science and Technology, Kun Ming 650050, \\ China. ${ }^{*}$ Corresponding author: yangyekm@163.com
}

\begin{abstract}
Indole-3-acetic acid (IAA) is hormones in higher plants and participates in plant growth regulation and stress resistance including Al stress. The reduction of root apex aluminum (Al) content by exogenous IAA treatment was hypothesized to be effective in alleviating the adverse effect of high Al concentration in wheat root growth. To investigate the role of IAA in lowering root apex Al content, Al-tolerant wheat (ET8) was studied in Al solution (50 $\mu \mathrm{M})$, co-treated with IAA $(25 \mu \mathrm{M})$ and anion channel inhibitors (5 $\mu \mathrm{M}$ NIF or A9C) or IAA transport inhibitors $\left(5 \mu \mathrm{M}\right.$ TIBA or NPA) under acidic condition for $24 \mathrm{~h}$. Treatments were as fellows: control $\left(0.5 \mu \mathrm{M} \mathrm{CaCl}_{2}\right), \mathrm{Al}$ $(50 \mu \mathrm{M}), \mathrm{Al}(50 \mu \mathrm{M})+\mathrm{IAA}(25 \mu \mathrm{M}), \mathrm{Al}(50 \mu \mathrm{M})+\mathrm{IAA}(25 \mu \mathrm{M})+\mathrm{NIF}$ (or A9C, $5 \mathrm{mM}), \mathrm{Al}(50 \mu \mathrm{M})+\mathrm{NPA}$ (or TIBA, $5 \mu \mathrm{M}$ ). Al content in root apex, rhizosphere $\mathrm{pH}$ and $\mathrm{PM} \mathrm{H}^{+}$-ATPase activity were studied. The results showed that co-treatment with IAA reduced root apex $\mathrm{Al}$ content by $42 \%$ compared to $\mathrm{Al}$ treatment. Anion channel inhibitors enhanced the accumulation of $\mathrm{Al}$ in root apex by $27 \%$ (or 32\%) (NIF or A9C), while addition of IAA neutralized its promoting effect. The co-treatment with IAA increased rhizosphere $\mathrm{pH}$ by alleviating the decrease of plasma membrane $\mathrm{H}^{+}$-ATPase activity, while IAA transport inhibitors (NPA or TIBA) suppressed the elevation of rhizosphere $\mathrm{pH}$. The current results suggested that IAA could be effective in alleviating Al toxicity through reducing $\mathrm{Al}$ accumulation in wheat root apex.
\end{abstract}

Keywords: Aluminum toxicity, indole-3-acetic acid, malic acid, rhizosphere $\mathrm{pH}, \mathrm{PM} \mathrm{H}^{+}$-ATPase

Abbreviations: A9C, Anthracene-9-carboxylic acid; NIF, Niflumic acid; NPA, N-1-napthyl-phtalamic acid; TIBA, 2,3,5-triiodobenzoic acid. 


\section{Introduction}

Indole-3-acetic acid is one of the most important signal hormones in higher plants, which not only functions as plant growth regulator but also as an essential stress resistant substance. It could relieve the inhibitory effect of $\mathrm{HgCl}_{2}$ on internodes diameter of sponge loofah Luffa cylindrica L. (Cucurbitaceace) (Khan and Chaudhry, 2006). It also has the potential of reducing the toxic effect of $\mathrm{Cu}^{2+}$ in sunflower (Helianthus annuus L.) roots and improving the stability of the light-harvesting complex photosystem 2 reaction centers (Ouzounidou and Ilias, 2005). IAA has been reported to regulate the activity of plant cell $\mathrm{PM} \mathrm{H}^{+}$ATPase. Six hours after imposing Fe deprivation, IAA concentration increased in shoots and roots, which in turn upregulates the activity of $\mathrm{PM} \mathrm{H}^{+}$-ATPase (rhizosphere $\mathrm{pH}$ ) in root apex of cucumber (Bacaicoa et al., 2011). Exogenous application of IAA stimulates the activity of $\mathrm{PM} \mathrm{H} \mathrm{H}^{+}$-ATPase and $\mathrm{P}$ uptake (Shen et al., 2006).

$\mathrm{Al}$ mainly exists as oxide or silicate precipitates in the crust of the Earth and is usually not toxic to plants. However, as the soil $\mathrm{pH}$ drops below 5 , the octahedral hexahydrate, $\mathrm{Al}\left(\mathrm{H}_{2} \mathrm{O}\right) 6^{3+}$, more commonly referred to as $\mathrm{A}^{3+}$, is solubilized into the soil solution. This form of $\mathrm{Al}$ is the most important rhizotoxic $\mathrm{Al}$ species to plant (Kinraide, 1991). On the other hand, there is a wide genetic variation of both intra and interspecies in Al tolerance, suggesting that Al-resistant species or cultivars possess several mechanisms for detoxifying Al. Two mechanisms are suggested for the detoxification of $\mathrm{Al}$, one is the exclusion of $\mathrm{Al}$ from the root apex (exclusion mechanism), and the other is the tolerance of Al that enters plant (internal tolerance mechanism) (Ma and Furukawa, 2003). With regard to possible exclusion mechanisms, these could include the secretion of Al-chelating organic acid from roots (Ma and Furukawa, 2003), Al-binding by mucilage secreted from roots (Cai et al., 2011) and the formation of a rhizosphere $\mathrm{pH}$ barrier (Wang et al., 2006; Yang et al., 2011a; Vidal-Bardán and Villa-Bermejo, 2012). Internal tolerant mechanisms could include $\mathrm{Al}$ fixation in the cell wall (Arroyave et al., 2011), complexation via organic ligands, and sequestration in the vacuole (Shen et al., 2002).

The uptake of Al by plant may cause both physiological disturbance as well as the structural damage (Claudio et al., 2011; Qin et al., 2010). However, a simple and effective way for detoxification is to reduce $\mathrm{Al}$ accumulation in root apex. Our earlier results indicated that IAA could increase the efflux of malic acid under Al stress (Yang et al., 2011b), but effects of IAA in root apex Al content were still waiting to be explored. As is known that exogenous IAA could enhance the efflux of malic acid and the increase of rhizosphere $\mathrm{pH}$, we therefore hypothesized that exogenous IAA treatment could be effective in reducing root apex aluminum ( $\mathrm{Al})$ content. The present study focused on

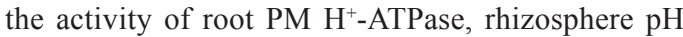
and $\mathrm{Al}$ content in root apex to elucidate the possible involvement of IAA in Al-tolerance of wheat roots exposed to Al stress.

\section{Materials and Methods}

\subsection{Plant materials and growth conditions}

The seeds line ET8 (Al-resistant) of wheat (Triticum aestivum L.) were surface-sterilised by immersing them in $1 \%(\mathrm{v} / \mathrm{v})$ sodium hypochlorite for $15 \mathrm{~min}$, rinsed several times, and soaked for $12 \mathrm{~h}$ with deionized water, before they were subjected to germination on a layer of moistened filter-paper at $25{ }^{\circ} \mathrm{C}$ for $24 \mathrm{~h}$ in darkness. The germinated seeds were transferred onto a cotton net floating on $0.5 \mathrm{mM}$ $\mathrm{CaCl}_{2}, \mathrm{pH} 4.5$ in a $2 \mathrm{~L}$ plastic container for 4 days. The uniform seedlings were selected for experiments which were carried out in a growth room with a day/ night temperature at $25 / 22{ }^{\circ} \mathrm{C}$ and $14 / 10 \mathrm{~h}$ duration, the light intensity of $150 \mu \mathrm{mol}$ photon $\mathrm{m}^{-2} \mathrm{~s}^{-1}$ at the plantcanopy level, and a relative air humidity of $70 \%$. 


\subsection{Treatments}

Five types of treatments were performed, which all contained $0.5 \mathrm{mM} \mathrm{CaCl}$. Four of the treatments were performed with $\mathrm{Al}(50 \mu \mathrm{M}), \mathrm{Al}(50 \mu \mathrm{M})+$ IAA $(25 \mu \mathrm{M}), \mathrm{Al}(50 \mu \mathrm{M})+\mathrm{IAA}(25 \mu \mathrm{M})+\mathrm{NIF}$ (or $\mathrm{A} 9 \mathrm{C}, 5 \mu \mathrm{M})$, and $\mathrm{Al}(50 \mu \mathrm{M})+\mathrm{NPA}$ (or TIBA, 5 $\mu \mathrm{M})$ respectively, and treatment with $0.5 \mathrm{mM} \mathrm{CaCl}_{2}$ as the control. All treatments started by exposing the seedlings for $24 \mathrm{~h}$ to $0.5 \mathrm{mM} \mathrm{CaCl} \mathrm{CH}_{2}$ 4.5) containing other chemicals.

\section{Al treatments}

Treatment 1 contains: CK; 25; 50 or $100 \mu \mathrm{M} \mathrm{Al}$ $\left(\mathrm{AlCl}_{3} \cdot 6 \mathrm{H}_{2} \mathrm{O}\right.$, Alfa Aesar, Lancaster). At sampling time, roots were briefly rinsed with distilled water and then three of the longest root apexes $(0-10 \mathrm{~mm})$ of each seedling were excised with a razor for the determination of $\mathrm{Al}$ content.

\section{IAA treatments}

Treatment 2 contains: CK; $50 \mu \mathrm{M} \mathrm{Al} ; 25 \mu \mathrm{M}$ IAA (Sigma, USA) and $50 \mu \mathrm{M}$ Al. At sampling time, rhizosphere $\mathrm{pH}$ was determined, then roots were briefly rinsed with distilled water and then three of the longest root apexes $(0-10 \mathrm{~mm})$ of each seedling were excised with a razor for the determination of $\mathrm{Al}$ content or $\mathrm{PM} \mathrm{H}^{+}$-ATPase activity.

\section{$A 9 C$ and NIF treatments}

Treatment 3 (or 4) contains: CK; $50 \mu \mathrm{M} \mathrm{Al} ; 50 \mu \mathrm{M}$ $\mathrm{Al}$ and $5 \mu \mathrm{M}$ A9C (or NIF) (Sigma, USA); $50 \mu \mathrm{M} \mathrm{Al}$, $5 \mu \mathrm{M}$ A9C (or NIF) and $25 \mu \mathrm{M}$ IAA, respectively. At sampling time, roots were briefly rinsed with distilled water and then three of the longest root apexes (0-10 $\mathrm{mm}$ ) of each seedling were excised with a razor for the determination of $\mathrm{Al}$ content.

\section{NPA and TIBA treatments}

Treatment 5 contains: CK; $50 \mu \mathrm{M} \mathrm{Al} ; 5 \mu \mathrm{M}$ NPA (Sigma, USA) and $50 \mu \mathrm{M} \mathrm{Al} ; 5 \mu \mathrm{M}$ TIBA and $50 \mu \mathrm{M}$
$\mathrm{Al}$ (Sigma, USA). At sampling time, rhizosphere $\mathrm{pH}$ was determined.

\subsection{Determination of rhizosphere $\mathrm{pH}$ and root apex Al content}

Rhizosphere $\mathrm{pH}$ was determined by $\mathrm{pH}$ Meter (Mettler FE-20, Shanghai). Al contents in root apexes (0-10 $\mathrm{mm}$ ) were determined by graphite furnace atomic absorption spectrometry (GFAAS Varian GTA 120, USA) (Osawa and Matsumoto, 2001).

\subsection{Preparation and determination of $P M H^{+}$-ATPase activity}

PM vesicles were prepared at $4{ }^{\circ} \mathrm{C}$ by the method of Palmgren et al. (1990). PM $\mathrm{H}^{+}$-ATPase activity was measured by the method of Johansson et al. (1995). The liberated $\mathrm{Pi}$ was measured with a spectrophotometer (Hitachi, U-1800, Japan) at $720 \mathrm{~nm}$. Membrane protein content was determined by the protein-dye binding method of Bradford (1976), using bovine serum albumin as the standard. PM $\mathrm{H}^{+}$-ATPase activity was expressed as relative $\mathrm{PM} \mathrm{H}^{+}$-ATPase activity $\left[\left(\mathrm{PM} \mathrm{H}^{+}\right.\right.$ATPase activity with $\mathrm{Al}$ treatment)/ $\left(\mathrm{PM} \mathrm{H}^{+}\right.$-ATPase activity without $\mathrm{Al}$ treatment $) \times 100$ ].

\subsection{Statistical analysis}

The experiments were done in triplicate, and data were pooled and subjected to one way analysis of variance (ANOVA) followed by Tukey-Kramer test. $P$ $\leq 0.05$ was set as the level of statistical significance. DPS v7.05 and OrigenPro7.5 software were used for computation, data analysis and graphics.

\section{Results}

\subsection{Effect of Al on root apex Al content}

Root apex Al contents were $0.05,0.13$ and $0.25 \mu \mathrm{g}$ root apex ${ }^{-1}$ respectively, under the treatments of 25 , 50 and $100 \mu \mathrm{M} \mathrm{Al}$. In the present study, root apex Al 
content significantly increased with the increase of $\mathrm{Al}$ concentrations (Figure 1). Meanwhile, severe visible Al-induced damage could be observed in the roots at the concentration above $50 \mu \mathrm{M} \mathrm{Al}$, therefore, $50 \mu \mathrm{M}$ $\mathrm{Al}$ was used for all further experiments.

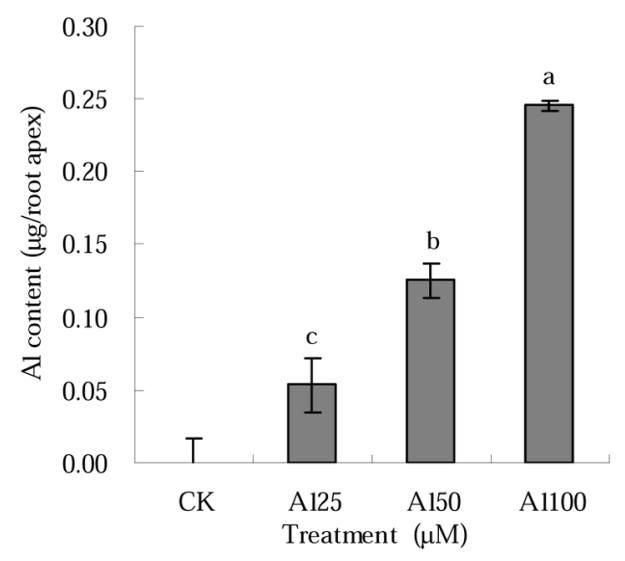

Figure 1. Al content in root apexes of wheat $24 \mathrm{~h}$ after exposure to three different concentrations $(25,150$ and $100 \mu \mathrm{M})$ of $\mathrm{Al}$. The values are mean $\pm \mathrm{SE}(\mathrm{n}=3)$.

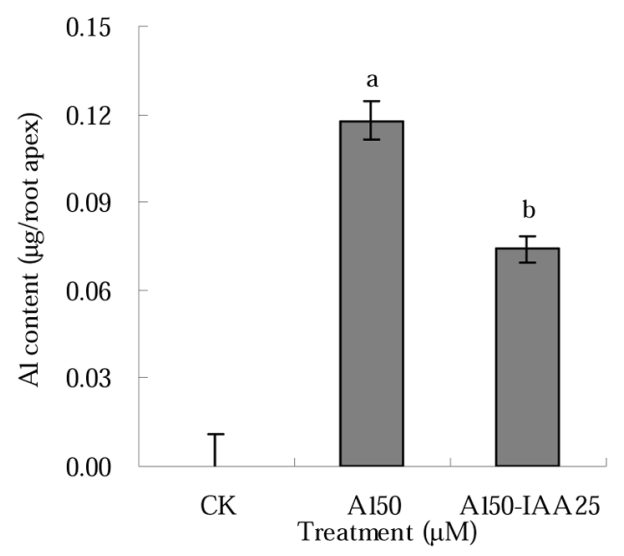

Figure 2. Effect of IAA on root apexes Al content in of wheat. The values are mean $\pm \mathrm{SE}(\mathrm{n}=3)$.

\subsection{Effect of IAA on root apex Al content}

The contents of $\mathrm{Al}$ in root apex were 0.12 and $0.07 \mathrm{mg}$ root ape $\mathrm{x}^{-1}$ under the treatments of $50 \mu \mathrm{M} \mathrm{Al}$ and $50 \mu \mathrm{M}$ $\mathrm{Al}+25$ mM IAA respectively (Figure 2). Al content in the group merely treated by $\mathrm{Al}$ was significantly higher than the groups co-treated by IAA with Al. It indicated that exogenous IAA could alleviate the accumulation of $\mathrm{Al}$ in root apex.

\subsection{Effect of anion channel inhibitors on root apex Al content}

In order to further confirm our speculation, anion channel inhibitor was applied in the following experiments. Al content in the root apex was 1.27 (or 1.32) times higher than the group treated merely by $50 \mu \mathrm{M} \mathrm{Al}$ after being treated with $5 \mu \mathrm{M}$ A9C (or NIF) $+50 \mu \mathrm{M} \mathrm{Al}$ (Figure $3)$. The changing trend was consistent with malic acid efflux characters in Figure S3. Root apex Al content of the group treated by $5 \mu \mathrm{M}$ A9C (or NIF) $+50 \mu \mathrm{M} \mathrm{Al}+$ $25 \mu \mathrm{M}$ IAA was higher than that merely treated by 50 $\mu \mathrm{M} \mathrm{Al}$, but was $10 \%$ (or $14 \%$ ) lower than the co-treated ones by $5 \mathrm{mM}$ A9C (or NIF) $+50 \mathrm{M} \mathrm{Al}$. This changing trend also consistent with the corresponding malic acid efflux changing trend (Figure S3).

The results described above further suggested that exogenous IAA could alleviate the $\mathrm{Al}$ accumulation in root apex.

\subsection{Effect of IAA on rhizosphere $\mathrm{pH}$}

Effects of exogenous IAA on rhizosphere $\mathrm{pH}$ were examined to investigate the role of IAA in Al resistant comprehensively. As shown in Figure 4, although the initial rhizosphere $\mathrm{pH}$ of all the treatments (CK, A150, $\mathrm{A} 150$ + IAA25) were 4.5 , obvious difference among these three treatments after $24 \mathrm{~h}$ could be observed. The rhizosphere $\mathrm{pH}$ of CK was $4.87,4.73$ of $50 \mu \mathrm{M}$ $\mathrm{Al}$ and 4.96 of $25 \mu \mathrm{M} \mathrm{IAA}+50 \mu \mathrm{M} \mathrm{Al}$ co-treatment. These results indicated that exogenous IAA could promote the elevation of rhizosphere $\mathrm{pH}$ of wheat under $\mathrm{Al}$ stress. 

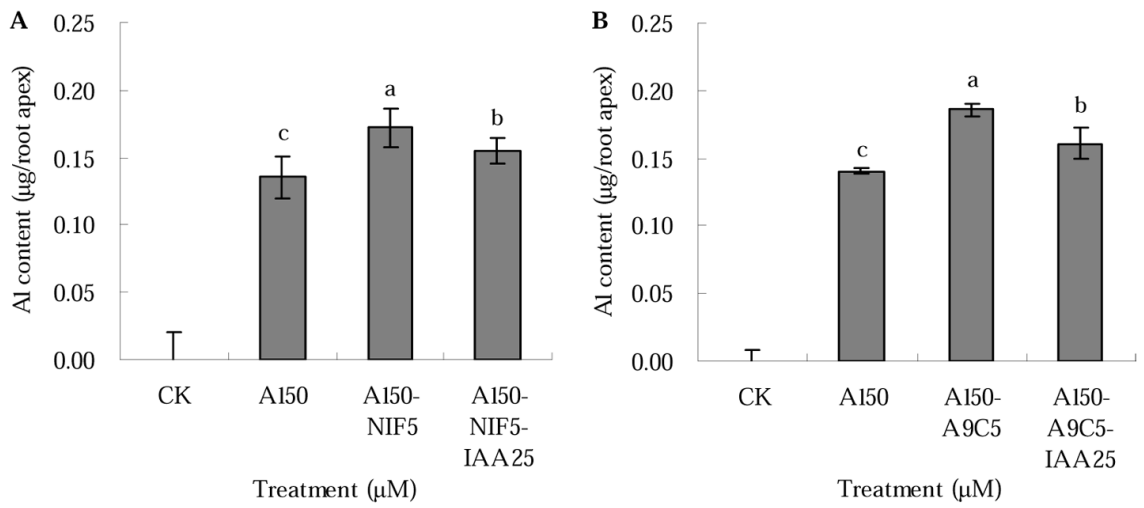

Figure 3. Effect of anion channel inhibitor (A9C, A or NIF, B) or IAA on root apexes Al content of wheat. The values are mean $\pm \operatorname{SE}(n=3)$.

In order to further confirm that IAA participated in regulating rhizosphere $\mathrm{pH}$, IAA transport inhibitors NPA and TIBA were applied. The rhizosphere $\mathrm{pH}$ of $50 \mu \mathrm{M} \mathrm{Al}$ and $5 \mu \mathrm{M}$ TIBA (or NPA) co-treated groups was significantly lower than $\mathrm{CK}$ or $50 \mu \mathrm{M}$ Al treated alone (Figure 5), which showed that NAP or TIBA inhibited the elevation of rhizosphere $\mathrm{pH}$, and this provided evidence that IAA was involved in promoting rhizosphere $\mathrm{pH}$.

\subsection{Effect of IAA on PM $H^{+}$-ATPase activity}

$\mathrm{PM} \mathrm{H}^{+}$-ATPase is known to regulate the charge balance and $\mathrm{H}^{+}$movement at plasma membrane surfaces. In order to investigate mechanisms of IAA regulated rhizosphere $\mathrm{pH}$, effects of IAA on PM $\mathrm{H}^{+}$-ATPase activity were studied (Figure 6). The relative PM $\mathrm{H}^{+}$-ATPase activity was $45.27 \%$ under the treatment of $50 \mu \mathrm{M} \mathrm{Al}$, which was significantly lower than the co-treatment of $50 \mu \mathrm{M}$ $\mathrm{Al}$ and $25 \mu \mathrm{M}$ IAA (59.84\%). The involvement of IAA in regulating $\mathrm{PM} \mathrm{H}^{+}$-ATPase activity was confirmed.

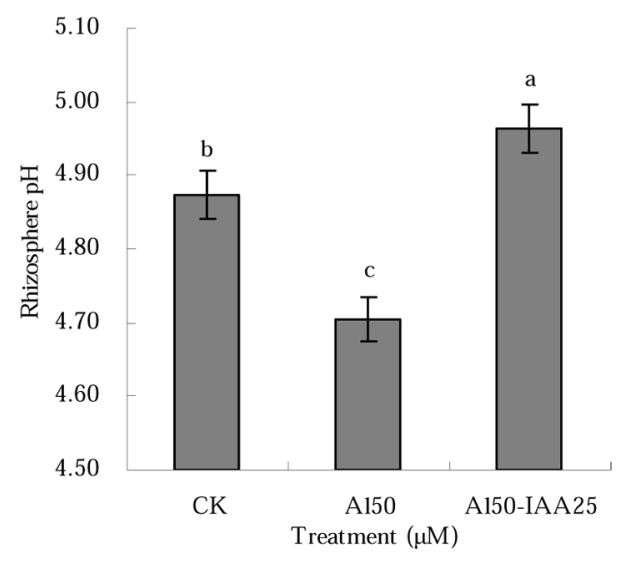

Figure 4. Effects of IAA on rhizosphere $\mathrm{pH}$ of wheat. The values are mean $\pm \operatorname{SE}(n=3)$. 


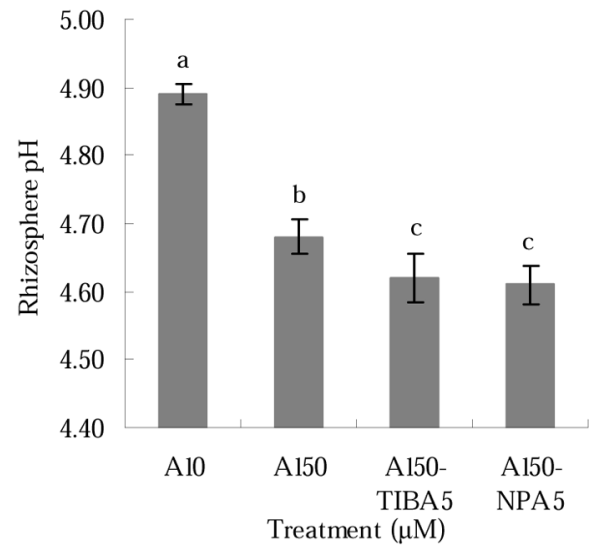

Figure 5. Effects of TIBA (or NPA) on rhizosphere $\mathrm{pH}$ of wheat. The values are mean $\pm \operatorname{SE}(n=3)$.

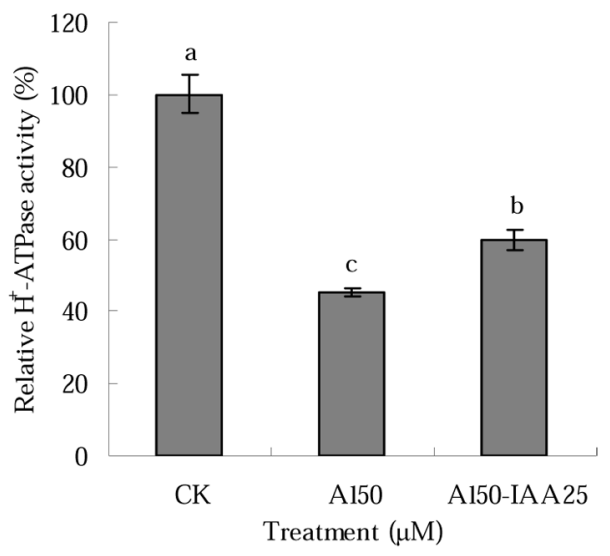

Figure 6. Effects of IAA on PM $\mathrm{H}^{+}$-ATPase activity of wheat root apex $(0-10 \mathrm{~mm})$. The values are mean $\pm \mathrm{SE}(\mathrm{n}=3)$.

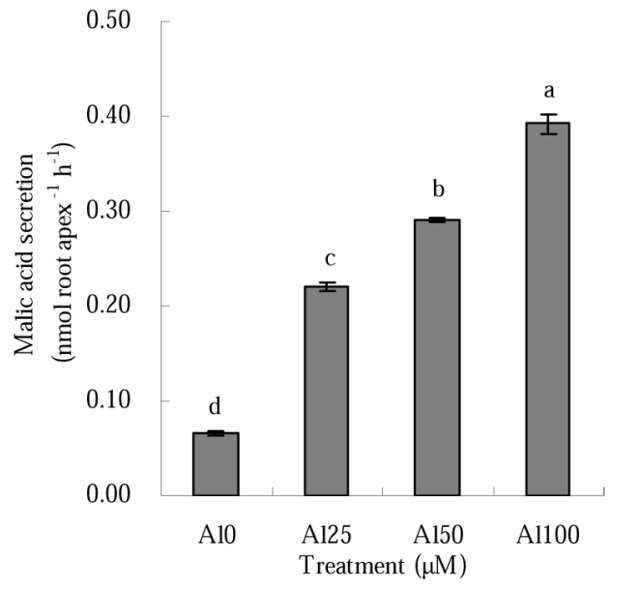

Figure S1. Dose-response of Al-induced malic acid efflux from wheat root after $24 \mathrm{~h}$ exposure to different concentrations $\mathrm{Al}$. The values are mean $(\mathrm{n}=3)$.

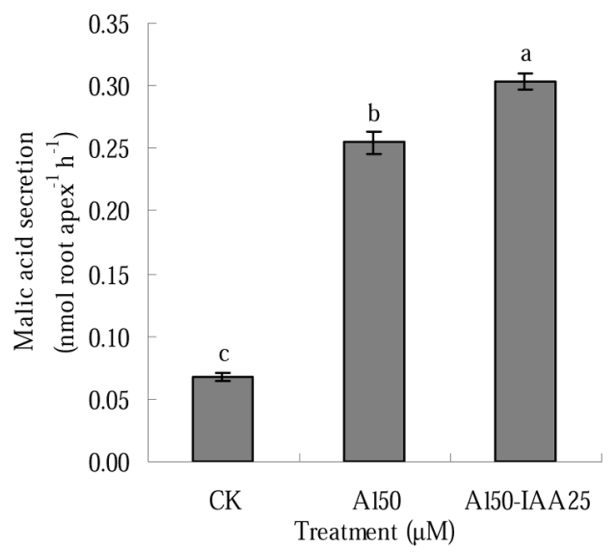

Figure S2. Effect of $50 \mu \mathrm{M} \mathrm{Al}$ and $25 \mu \mathrm{M}$ IAA cotreatment for $24 \mathrm{~h}$ on malic acid efflux from wheat. The values are mean $\pm \operatorname{SE}(n=3)$. 

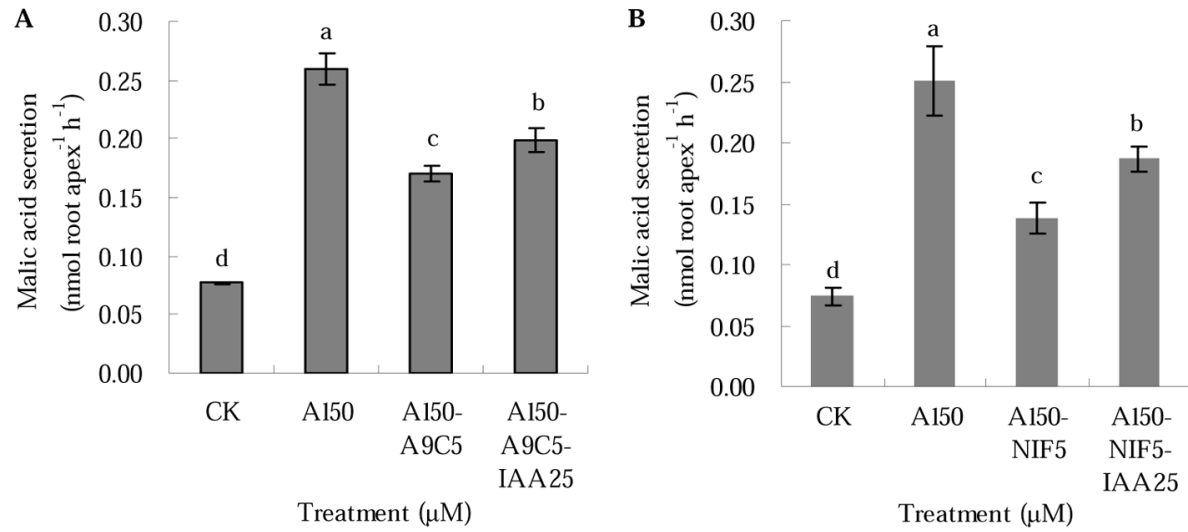

Figure S3. Effect of anion channel inhibitor (A9C, A or NIF, B) or IAA on malic acid efflux from wheat. The values are mean $(n=3)$.

\section{Discussion}

IAA is an important signal substance in plants that extensively participates in environmental stresses. Salt-tolerance of wheat can be improved significantly by soaking seeds in IAA (Iqbal and Ashraf, 2007). When Medicago truncatula is nodulated by an IAA-overproducing Sinorhizobium meliloti strain, it increases tolerance to high $\left(55^{\circ} \mathrm{C}\right)$ or low $\left(4{ }^{\circ} \mathrm{C}\right)$ temperature, UV-irradiation, $\mathrm{NaCl}$ stress $(0.5 \mathrm{M})$ and low pH (3) (Bianco and Defez, 2009).

Al mainly accumulates in plant root apex within 0-10 $\mathrm{mm}$ and is toxic to cells (Tahara et al., 2008; Yang et al., 2011c). Organic acid secreted by plants roots possesses higher binding capacity with rhizosphere active $\mathrm{Al}$, which could reduce the binding of $\mathrm{Al}$ to root cells (Ma and Furukawa, 2003). Reducing the root apex Al content could be an effective way to improve Al resistance (Reyes-Díaz et al, 2011). To promote the efflux of malic acid is a prominent way to resist $\mathrm{Al}$ toxicity of wheat. In the present study, Al contents in the root apex increased with the elevation of Al content in culture solution significantly (Figure 1), and malic acid was induced by $\mathrm{Al}$ in a dose-dependent manner (Figure S1), which was in consistence with the study of Zhao et al . (2003).

Our earlier results indicated that IAA could increase the efflux of malic acid under Al stress (Yang et al., 2011b), which was reproduced in this study (Figure S2). Exogenous IAA could cause difference of malic acid efflux between treatments of $\mathrm{Al}$ and IAA $+\mathrm{Al}$ respectively. The effects of IAA on Al content of root apex $(0-10 \mathrm{~mm})$ of wheat were studied to investigate the role of IAA in Al-resistance. Figure 2 showed that IAA could reduce the accumulation of $\mathrm{Al}$ in root apex. We speculated that IAA could enhance efflux of Alchelating malic acid, which led to the decrease of $\mathrm{Al}$ content in root apex. In order to further confirm our speculation, anion channel inhibitor was applied in our study. IAA relieved the inhibiting effect of A9C (or NIF) on Al induced malic acid efflux (Figure S3), which consisted with our previous results (Yang et al., 2011b). In accordance with these changing characters, IAA abolished the promoting effects of anion channel inhibitor on $\mathrm{Al}$ accumulation in root apex (Figure 3). 
The reduction of $\mathrm{Al}$ content in root apex could further confirm that IAA participated in Al-resistance.

As mentioned previously, efflux of organic acid is a main but not the only mechanism of plant to resist Al toxicity, the elevation of rhizosphere $\mathrm{pH}$ is also a barrier to defect Al stress (Wang et al., 2006). Yang et al. (2011a) reports that at low rhizosphere $\mathrm{pH}$ condition $(\mathrm{pH}<5.00)$, root apex $\mathrm{Al}$ content decreased with the increase of rhizosphere $\mathrm{pH}$. There was a significant negative correlation between all the date of rhizosphere $\mathrm{pH}$ and $\mathrm{Al}$ content in root apex. In present study, exogenous IAA could promote the elevation of rhizosphere $\mathrm{pH}$ of wheat under $\mathrm{Al}$ stress (Figure 4), which indicated that IAA participated in $\mathrm{Al}$ resistance not only by inducing malic acid efflux but also by increasing rhizosphere $\mathrm{pH}$.

In order to further confirm that IAA participated in regulating rhizosphere $\mathrm{pH}, \mathrm{NPA}$ and TIBA were applied in this study. NPA and TIBA are IAA transport inhibitors, which can cause the accumulation of IAA in the merismatic zone and insufficient accumulation in the elongation zone (Kollmeier et al., 2000). Our results showed that NAP or TIBA treatment inhibited the elevation of rhizosphere $\mathrm{pH}$ (Figure 5), which provided further evidence that IAA was involved in the promotion of rhizosphere $\mathrm{pH}$ under $\mathrm{Al}$ stress.

$\mathrm{PM} \mathrm{H}^{+}$-ATPase is known to regulate the charge balance and $\mathrm{H}^{+}$movement at plasma membrane surfaces. It is of great significance for plant survival under a variety of external stresses (Cui et al., 2010). Bose et al. (2010) find that Arabidopsis thaliana could increase rhizosphere $\mathrm{pH}$ by the uptake of rhizosphere $\mathrm{H}^{+}$under low-pH stress $(\mathrm{pH}=4.2)$, but this process could be abolished by Al exposure. That IAA participates in the regulation of plant cell $\mathrm{PM} \mathrm{H}^{+}$-ATPase activity has been proved. Bacaicoa et al. (2011) report that Festarved plants show an increase in IAA concentration in shoots and roots after 6 and $24 \mathrm{~h}$ from the beginning of the treatments, which in turn upregulates the activity of PM $\mathrm{H}^{+}$-ATPase (rhizosphere $\mathrm{pH}$ ) in root apex of cucumber. Shen et al. (2006) have studied $\mathrm{PM} \mathrm{H}^{+}-$
ATPase activity of soybean root under $\mathrm{Al}$ stress, and confirmed that exogenous IAA could stimulate the activity of PM $\mathrm{H}^{+}$-ATPase and P uptake, while NPA blocked IAA effects.

Consistent with the study of Yang et al. (2011a), Al treatment markedly inhibited the activity of $\mathrm{PM} \mathrm{H}^{+}$ ATPase in the present study (Figure 6). But this inhibiting effect could be abolished by exposing to exogenous IAA. The relative $\mathrm{PM} \mathrm{H}^{+}$-ATPase activity of the IAA and Al co-treatment was significantly higher than the mere $\mathrm{Al}$ treatment. So IAA participated in regulating rhizosphere $\mathrm{pH}$ by acting on $\mathrm{PM} \mathrm{H}^{+}$-ATPase directly or indirectly was speculated. Previous studies of Yang et al. (2011a) find that there is a significant

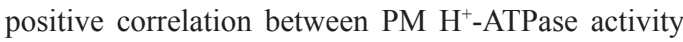
and rhizosphere $\mathrm{pH}$. Rhizosphere $\mathrm{pH}$ of the IAA and Al co-treated group was shown to be significantly higher than the control group in this research (Figure 5), while the $\mathrm{PM} \mathrm{H}^{+}$-ATPase activity was significantly lower than the control group (Figure 6), which was not fully consistent with the previous results of Yang et al. (2011a). So we could deduce that IAA up-regulated rhizosphere $\mathrm{pH}$ not only by regulating $\mathrm{PM} \mathrm{H}^{+}$- ATPase, but also other mechanisms.

\section{Conclusions}

The current results suggested that IAA could be effective in alleviating $\mathrm{Al}$ toxicity through reducing $\mathrm{Al}$ accumulation in wheat root apex. Inducing efflux of malic acid by IAA and increasing rhizosphere $\mathrm{pH}$ could be considered the two effective ways to improve the resistance of plants to A1. Our study was to confirm that exogenous indole-3-acetic acid could reduce the accumulation of aluminum in root apex of wheat under Al stress. Further research is under way in our laboratory to explore the main mechanism and the contribution rate. 


\section{Acknowledgements}

We thank Dr. Ma Jian Feng of the Research Institution for Bioresources of Okayama University for the ET8 seeds. We also would like to thank Natural Science Foundation of China (Project No. 31201677) for financial support. Our appreciation also goes to Professor Liu Yanxiu for her help in improving our writing in English.

\section{References}

Arroyave, C., Barceló, J., Poschenrieder, C., Tolrà, R. 2011. Aluminium-induced changes in root epidermal cell patterning, a distinctive feature of hyperresistance to $\mathrm{Al}$ in Brachiaria decumbens. J. Inorg. Biochem. 105, 1477-1483.

Bacaicoa, E., Mora, V., Zamarreño, Á.M., Fuentes, M., Casanova, E., García-Mina, J. M. 2011. Auxin: A major player in the shoot-to-root regulation of root Fe-stress physiological responses to Fe deficiency in cucumber plants. Plant Physiol. Biochem. 49, 545-556.

Bianco, C., Defez, R. 2009. Medicago truncatula improves salt tolerance when nodulated by an indole-3-acetic acid overproducing Sinorhizobium meliloti strain. J. Exp. Bot. 60, 3097-3107.

Bose, J., Babourina, O., Shabala, S., Rengel, Z. 2010. Aluminium-induced ion transport in Arabidopsis: the relationship between $\mathrm{Al}$ tolerance and root ion flux. J. Exp. Bot. 61, 3163-3175.

Bradford, M.M. 1976. Rapid and sensitive method for quantization of microgram quantities of proteinutilizing principle of protein-dye binding. Anal. Biochem. 72, 248-254.

Cai, M., Wang, F., Li, R., Zhang, S., Wang, N., Xu, G. 2011. Response and tolerance of root border cells to aluminum toxicity in soybean seedlings. J. Inorg. Biochem. 105, 966-971.
Claudio, I., Marjorie, R., Felipe, A., Adriano, N., Miren, A., Patricio, A. 2011. Biochemical and molecular changes in response to aluminium-stress in highbush blueberry (Vaccinium corymbosum L.). Plant Physiol. Biochem. 49, 1005-1012.

Cui, X. M., Zhang, Y. K., Wu, X. B., Liu, C. S. 2010. The investigation of the alleviated effect of copper toxicity by exogenous nitric oxide in tomato plants. Plant Soil Environ. 56, 274-281.

Iqbal, M., Ashraf, M. 2007. Seed treatment with auxins modulates growth and ion partitioning in salt-stressed wheat plants. J. Integr. Plant Biol. 49, 1003-1015.

Johansson, F., Olbe, M., Sommarin, M., Larsson, C. 1995. Brij 58, a polyoxyethylene acyl ether, creates membrane vesicles of uniform sideness: a new tool to obtain inside-out (cytoplasmic side-out) plasma membrane vesicles. Plant J. 7, 165-173.

Khan, A. S., Chaudhry, N. Y. 2006. Auxins partially restore the cambial activity in Luffa cylindrica $\mathrm{L}$. (Cucurbitaceace) under mercury stress. J. Food Agric. Environ. 4, 276-281.

Kinraide, T.B. 1991. Identity of the rhizotoxic aluminum species. Plant Soil. 134, 167-178.

Kollmeier, M., Felle, H.H., Horst, W.J. 2000. Genotypical differences in aluminum resistance of maize are expressed in the distal part of the transition zone. Is reduced basipetal auxin flow involved in inhibition of root elongation by aluminum?. Plant Physiol. 122, 945-956.

Ma, J.F., Furukawa, J. 2003. Recent progress in the research of external Al detoxification in higher plants: a minireview. J. Inorg. Biochem. 97, 46-51.

Osawa H, Matsumoto H. 2001. Possible involvement of protein phosphorylation in aluminumresponsive malate efflux from wheat root apex. Plant Physiol. 126. 411-420. 
Ouzounidou, G., Ilias, I. 2005. Hormone-induced protection of sunflower photosynthetic apparatus against copper toxicity. Biol. Plantarum. 49, $223-$ 228.

Palmgren, M.G., Askerlund, P., Fredrikson, K., Widell, S., Sommarin, M., Larsson, C. 1990. Sealed insideout plasma membrane vesicles: optimal conditions for formation and separation. Plant Physiol. 92, 871-880.

Qin, R., Jiao, Y., Zhang, S., Jiang, W., Liu, D. 2010. Effects of aluminum on nucleoli in root tip cells and selected physiological and biochemical characters in Allium cepa var. agrogarum L. BMC Plant Biol. 10, 1471-2229.

Reyes-Díaz, M., Meriño-Gergichevich,C., Alarcón, E., Alberdi, M., Horst., W. J. 2011. Calcium sulfate ameliorates the effect of aluminum toxicity differentially in genotypes of highbush blueberry (Vaccinium corymbosum L.). J. Soil Sci. Plant Nutr. 11(4): 59-78.

Shen, H., Chen, J., Wang, Z., Yang, C., Sasaki, T., Yamamoto, Y., Matsumoto, H., Yan, X. 2006. Root plasma membrane $\mathrm{H}^{+}$-ATPase is involved in the adaptation of soybean to phosphorus starvation. J. Exp. Bot. 57, 1353-1362.

Shen, R., Ma, J.F., Kyo, M., Iwashita, T. 2002. Compartmentation of aluminium in leaves of an Al-accumulator, Fagopyrum esculentum Moench. Planta. 215, 394-398.

Tahara, K., Ymahoshita, T., Norisada, M., Hasegawa, I., Kasshima, H., Sasaki, S., Kojma, K. 2008. Aluminum distribution and reactive oxygen species accumulation in root tips of two melaleuca trees differing in aluminum resistance. Plant Soil. $307,167-178$.
Vidal-Bardán, M., Villa-Bermejo, E. 2012. Fractionation of extractable aluminium and biomass production in an acid soil treated with calcareous amendments. Span. J. Agric. Res. 10(2): 513-520.

Wang, P., Bi, S., Ma, L., Han, W. 2006. Aluminum tolerance of two wheat cultivars (Brevor and Atlas60) in relation to their rhizosphere $\mathrm{pH}$ and organic acids exuded from roots. J. Agric. Food Chem. 54, 10033-10039.

Yang, Y., Wang, Q.L., Geng, M. J., Guo, Z.H., Zhao, Z. 2011a. Rhizosphere $\mathrm{pH}$ difference regulated by plasma membrane $\mathrm{H}^{+}$-ATPase is related to differential Al-tolerance of two wheat cultivars. Plant Soil Environ. 57, 201-206.

Yang, Y., Wang, Q., Geng, M., Guo, Z., Zhao, Z. 2011b. Effect of indole-3-acetic acid on aluminuminduced efflux of malic acid from wheat (Triticum aestivum L.). Plant Soil. 346, 215-230.

Yang, Y., Wang, Q., Geng, M., Guo, Z., Zhao, Z. 2011c. Al-induced root cell wall chemical components differences of wheat (Triticum aestivum L.) with different Al tolerances. Afr. J. Biotechnol. 10(35): 6762-6772.

Zhao, Z., Ma J.F., Sato, K., Takeda, K. 2003. Differential Al resistance and citrate secretion in barley (Hordeum vulgare L.). Planta. 217, 794 800. 